\title{
NUTRITIONAL INTAKE OF SLOVENIAN SEMI-PROFESSIONAL HANDBALL PLAYERS
}

\author{
Kaja TERAŽ ${ }^{1}$ \& Cécil J. W. MEULENBERG ${ }^{1}$ \\ ${ }^{1}$ Science and Research Centre Koper, Institute for Kinesiology Research, Slovenia \\ Corresponding author: \\ Kaja TERAŽ \\ Science and Research Centre Koper, Institute for Kinesiology Research \\ Garibaldijeva 1, SI-6000 Koper, Slovenia \\ Phone: +38631424233 \\ E-mail:kaja.teraz@zrs-kp.si
}

\section{ABSTRACT}

Aim: Handball is a highly popular team sport, both in Slovenia and globally. The performance during team sport matches is influenced by numerous factors, amongst others there is nutrition whose influence is lesser known, particularly since diet is often uncontrolled. The purpose of this paper is to investigate whether Slovenian handball players, on basis of their anthropometric data and nutritional recommendations, have adequate nutritional intakes of energy and macronutrients.

Methods: Two Slovenian handball teams with male and female players (17 males and 9 females) who are part of the $1 A$ national league, were assessed through a 7-day food diary to define their nutritional intake in three different conditions for males (on their training days, match days and days off) and in two conditions for females (on their training days and days off). Basal anthropometric data were measured by standard methods and the body composition by a bioelectrical impedance scale. The results were statistically analysed with IBM SPSS programme, using the repeated measures ANOVA model.

Results: Both female and male handball players show insufficient amounts of energy intake, based on the most recent nutritional intake recommendations for team sports. Moreover, the intake of carbohydrates is too low for both female and male handball players, and the intake of fat is too high.

Conclusion: The analysis of the initial nutritional intake and the comparison with the recommendation shows that the male handball players do not have an optimal diet with proper intake of both energy and macronutrients. The energy intake is insufficient 
Kaja TERAŽ, Cécil J. W. MEULENBERG: NUTRITIONAL INTAKE OF SLOVENIAN SEMI-PROFESSIONAL HANDBALL PLAYERS, 129-147

also in female players. Adjusting the nutritional intake in a way to make it more balanced and tuned to the training schedule, would support a better health and performance.

Keywords: energy intake, macronutrients, nutrition, body composition, handball, team sport.

\section{PREHRANSKI VNOS ENERGIJE PRI SLOVENSKIH POLPROFESIONALNIH ROKOMETAŠIH IN ROKOMETAŠICAH}

\section{IZVLE $\check{C} E K$}

Namen: Rokomet je eden od bolj razširjenih ekipnih športov v Sloveniji in svetu. Tako kot na vse druge športe, tudi na rokomet vplivajo številni dejavniki. Eden izmed njih je tudi prehrana. Namen raziskave je ugotoviti ali imajo slovenski rokometaši ustrezen vnos energije in makrohranil.

Metode: V raziskavi sta sodelovali 2 rokometni ekipi 1.a slovenske lige, sodelovalo je 26 rokometašev in rokometašic (17 moških in 9 žensk). Podatke o prehranskem vnosu pri rokometaših in rokometašicah smo $v$ treh različnih okoliščinah (na dan treninga, na dan tekme in na prost dan) zbirali 1 teden. Prehranski vnos smo ocenili z metodo prehranskega dnevnika, telesno sestavo smo izmerili z bioimpedančno tehtnico. Podatke smo obdelali v računalniškem programu IBM SPSS, uporabili smo model ANOVA.

Rezultati: Tako rokometaši kot tudi rokometašice nimajo zadostnega energijskega vnosa. Nadalje, oboji imajo prenizek vnos ogljikovih hidratov ter previsok vnos maščob.

Zaključki: Ugotovili smo, da rokometaši, ki so sodelovali v raziskavi, nimajo optimalne prehrane z ustreznim vnosom energije in makrohranil, ki bi podpirala njihovo zdravje in zmogljivost. Tudi energijski vnos pri rokometašicah je prenizek. S prilagoditvijo prehrane svojim potrebam, bi lahko rokometaši dosegali boljše rezultate na treningu in tekmah.

Ključne besede: energijski vnos, makrohranila, prehrana, telesna sestava, rokomet, moštveni šport. 


\section{INTRODUCTION}

An athlete's performance is dependent on many different factors, one of them is nutrition (Thomas, Erdman, \& Burke, 2016). Nutritional habits are not permanent and athletes generally adapt their intake to the training periodization (Thomas et al., 2016), with specific athletes adopting specific nutritional strategies. The benefits of adequate nutrition are multiple and lead to better training and performance and quicker recovery, while having lower risk of illness or injury (International Olympic Committee, 2011; Kreider et al., 2010; Rodriquez, DiMarco, \& Langley, 2009).

On the other hand, athletes might adhere to diets that do not always meet their energy and nutrient requirements (Spronk, Heaney, Prvan, \& O'Connor, 2015). A recent systematic literature review, showed that especially team sport athletes do not meet the dietary recommendations (Jenner, Buckley, Belski, Devlin, \& Forsyth, 2019). This review emphasizes the need for sport-specific dietary recommendations for both professional and semi-professional players. Further, it was observed that the recommendations were fulfilled or exceeded for protein and or fat intake, but that the recommendations for both energy and carbohydrates, generally, were not met (Jenner et al., 2019).

Handball is a highly popular team sport in Slovenia and widely practiced on both professional and semi-professional levels, but it is not known whether Slovenian handball players meet the recommendations for nutritional intake. The aim of this paper was to evaluate whether the nutritional intakes in Slovenian handball players meet the recommendations. Thus, we did a literature search to establish the current sport-specific recommendations, and to make a comparison with the actual food intake, we measured the anthropometric and body index parameters and recorded the food intakes for one week of two semi-professional handball teams, both males and females.

\section{METHODS}

\section{Participants}

The survey was conducted in Koper, Slovenia among two semi-professional national handball clubs (a male team of the Rokometno društvo Koper 2013, and a female team of the Žensko rokometno društvo Koper), which included 26 players in total (17 males and 9 females). 


\section{Data Collection}

The anthropometric properties of the handball players were measured through standard methods at the University Kinesiology Centre in Koper. Body weight and body composition were measured with a Tanita MC-980 bioimpedance scale (Tanita Corporation Co., USA) and body height with a standardized meter. All anthropometric measurements were made in the morning.

After receiving the ethical committee approval, the subjects recorded their food and fluid intake for 7 days, one microcycle (a week of training). The food intake data were collected for both male (on training days, match days and days off) and female (training, days off) handball players from March 29 to April 4, 2016.

The individual dietary logs provided detailed information on food intake. For male players we collected information on food intake for 4 days of training, 1 match day and 2 days off. For female players we collected information on food intake for 5 days of training and 2 days off. For all specific days (training, match or days off) we calculated average values (where that was possible). Food diaries were processed using the online tool for monitoring eating habits: Open Platform for Clinical Nutrition (abbreviated as OPKP in Slovenia). At the training and preparatory match days, the researchers were present to ask the participants to promptly submit their written diaries.

The trainers of the teams provided the training schedule. Hence, it was possible for the researcher to record the time of active participation during the match and also during the training. This information was used to accurately estimate the energy requirements of each individual player.

The total energy expenditure requirements (TEEs) were calculated as the sum of the energy needs arising from the resting metabolism, the energy requirements for offtraining physical activity level (PAL), and the energy training requirements.

The resting energy expenditure (REE) was calculated by the predictive equation given by Cunningham et al. (1980): $\mathrm{RMR}=500+(22 \mathrm{x}$ fat free mass in $\mathrm{kg})$, based on the individual's fat free mass (FFM).

Recommendations for individual's daily energy intake, the recommended daily energy intakes (RDEIs) were calculated from the following formulas (both in kcal):

RDEI for training days and match days $=$ REE $\times 1.4+($ MET $\times$ body mass $\times h)$;

RDEI for days off $=\mathrm{REE} \times 1.6$,

using the PAL of 1.4 for training days and match days (which covers all daily activities outside the training or match (Debeljak, Debeljak, Hlastan-Ribič, Salobir, \& Pokorn, 2004), and 1.6 for days off (Debeljak et al., 2004). On the day of training and match, the value was multiplied by the metabolic equivalent (MET, defined as the metabolic energy expenditure for sitting quietly, Ainsworth et al. 2011), with a value of 8 for training days and 12 for match days, to capture the energy need for 90 minutes of training or match, respectively (Ainsworth et al., 2011). 


\section{Statistical Analysis}

The food diaries data were statistically processed in Microsoft Office Excel 2013 and IBM SPSS Statistics for Windows, version 22.0 software (IBM Corp, Armonk, New York, USA, 2013). Basic statistical methods (i.e., descriptive statistics) were used to compare the group characteristics. For independent samples, the statistical analysis of variance (ANOVA) for repeated measurements and post-hoc tests (Tukey LSD post-hoc comparison) were used. A p value less than 0.025 was considered statistically significant.

\section{RESULTS}

\section{Characteristics of the Subjects}

Tables 1 and 2 show the anthropometric values of male and female handball players respectively. The tables show the average data and standard deviations of age, height, body mass (BM), body mass index (BMI), estimated percentage of body fat, fat free mass (FFM), and visceral fat level for both genders, as well as specified for the handball players' playing position.

For men, the left and right backs are the tallest players with an average height of 191.0 centimeters, followed by the line players with an average height of 187.8 centimeters, then goalkeepers with an average height of 187.0 centimeters, centre-back players with an average height of $183.5 \mathrm{~cm}$. While the smallest in height are the wing players with an average of $177.5 \mathrm{~cm}$.

The line players have the highest percentage of fat among the male handball players (18.6\%), followed by left and right backs (16.9\%), then centre-back players $(16.7 \%)$, followed by goalkeepers $(14.4 \%)$, while the left and right wings have the lowest fat percentages $(12.4 \%)$. In the present male handball players, the largest FMM was observed in the backs $(78.2 \mathrm{~kg})$, followed by the line players $(76.4 \mathrm{~kg})$. Goalkeepers and wings had similar amounts of FFM $(71.6 \mathrm{~kg})$. The centre-back players had the smallest amount of FFM $(70.7 \mathrm{~kg})$.

Regarding the height of the female players, the line player was the tallest (178.3 $\mathrm{cm})$, followed by the back players $(177.7 \mathrm{~cm})$, then the goalkeepers $(174.1 \mathrm{~cm})$, the wing player $(167.8 \mathrm{~cm})$, and the shortest was the centre-back player $(165.0 \mathrm{~cm})$. Further, the female players reported the largest percentage of body fat among the wing players $(32.3 \%)$, followed by the goalkeepers $(29.3 \%)$, then the line player $(23.5 \%)$, and the back players $(23.1 \%)$, while the centre-back player had the lowest percentage of body fat $(22.7 \%)$. 


\begin{tabular}{|c|c|c|c|c|c|c|c|}
\hline 퓰 $\frac{E}{\|}$ & $\begin{array}{l}\stackrel{\eta}{+} \\
\ddot{H} \\
\vec{\sim}\end{array}$ & $\begin{array}{l}-\vec{b} \\
+1 \\
\infty \\
\dot{0} \\
\infty\end{array}$ & $\begin{array}{l}a \\
0 \\
+1 \\
\dot{0} \\
\dot{0}\end{array}$ & $\begin{array}{l}n \\
i \\
+1 \\
\hat{n} \\
\ddot{n}\end{array}$ & $\begin{array}{l}n \\
\ddot{n} \\
+ \\
\tilde{n} \\
0\end{array}$ & $\begin{array}{l}ت \dot{n} \\
+ \\
9 \\
\dot{I}\end{array}$ & $\frac{\infty}{\ddot{H}}$ \\
\hline 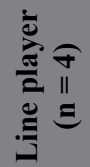 & $\begin{array}{l}m \\
m \\
+ \\
m \\
\dot{v}\end{array}$ & $\begin{array}{l}\vec{n} \\
+ \\
\infty \\
\infty \\
\infty \\
\infty\end{array}$ & $\begin{array}{l}n \\
n \\
H \\
\\
a\end{array}$ & $\begin{array}{l}\tilde{0} \\
+1 \\
\tilde{0} \\
\tilde{v}\end{array}$ & $\begin{array}{l}\infty \\
\stackrel{\infty}{+} \\
+1 \\
0 \\
\dot{\infty} \\
-\end{array}$ & $\begin{array}{l}\infty \\
\dot{n} \\
H \\
+ \\
\dot{\sigma}\end{array}$ & $\begin{array}{l}n \\
H \\
\infty \\
\infty \\
\dot{n}\end{array}$ \\
\hline 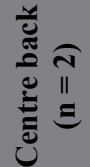 & $\begin{array}{l}\stackrel{+}{+} \\
+ \\
0 \\
\dot{+} \\
\text {. }\end{array}$ & $\begin{array}{l}\vec{i} \\
H \\
n \\
\tilde{\infty} \\
\infty\end{array}$ & $\begin{array}{l}a \\
\dot{n} \\
H \\
\dot{+} \\
\dot{\infty}\end{array}$ & $\begin{array}{l}m \\
i \\
+1 \\
\ddot{n}\end{array}$ & 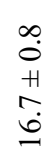 & $\begin{array}{l}\vec{n} \\
+ \\
r \\
\dot{0}\end{array}$ & $\begin{array}{l}0 \\
0 \\
+1 \\
0 \\
\dot{+}\end{array}$ \\
\hline 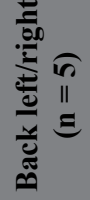 & $\begin{array}{l}n \\
i n \\
+1 \\
0 \\
\dot{n}\end{array}$ & $\begin{array}{l}0 \\
\dot{n} \\
H \\
0 \\
\dot{a} \\
\underline{a}\end{array}$ & $\begin{array}{l}\infty \\
\dot{n} \\
H \\
\dot{0} \\
\dot{0} \\
\sigma a\end{array}$ & $\begin{array}{l}0 \\
i \\
+ \\
n \\
n \\
\dot{0}\end{array}$ & 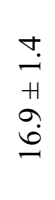 & $\begin{array}{l}9 \\
+ \\
+ \\
\sim \\
\infty \\
\infty\end{array}$ & $\begin{array}{l}\stackrel{0}{-} \\
\stackrel{H}{H} \\
8 \\
\dot{8}\end{array}$ \\
\hline 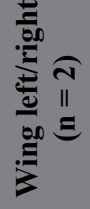 & 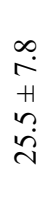 & $\begin{array}{l}\hat{O} \\
+1 \\
n \\
\hat{N}\end{array}$ & $\begin{array}{l}0 \\
\dot{0} \\
+1 \\
0 \\
\dot{0}\end{array}$ & $\begin{array}{l}\stackrel{I}{1} \\
+ \\
\sim \\
\infty \\
\infty\end{array}$ & $\begin{array}{l}0 \\
i \\
+ \\
+ \\
\dot{I} \\
\stackrel{I}{I}\end{array}$ & $\begin{array}{l}n \\
+1 \\
0 \\
\stackrel{1}{r}\end{array}$ & $\begin{array}{l}\stackrel{+}{.} \\
\dot{H} \\
0 \\
\dot{i}\end{array}$ \\
\hline 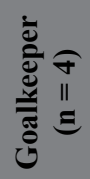 & $\begin{array}{l}0 \\
\dot{n} \\
+1 \\
\infty \\
\dot{\sim}\end{array}$ & $\begin{array}{l}\hat{\sigma} \\
+1 \\
0 \\
\dot{0} \\
0\end{array}$ & $\begin{array}{l}\dot{\forall} \\
+ \\
+ \\
\infty \\
\dot{\infty}\end{array}$ & $\begin{array}{l}\dot{v} \\
\ddot{r} \\
+ \\
\dot{d} \\
\ddot{d}\end{array}$ & $\begin{array}{l}\vec{r} \\
\dot{+} \\
+ \\
\dot{+}\end{array}$ & $\begin{array}{l}0 \\
\stackrel{+}{H} \\
0 \\
\stackrel{-}{r}\end{array}$ & $\begin{array}{l}0 \\
\dot{r} \\
+ \\
n \\
n\end{array}$ \\
\hline$\frac{\frac{0}{0}}{\frac{\pi}{\pi}}$ & 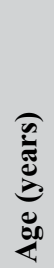 & 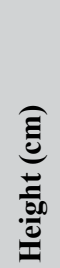 & 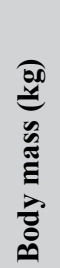 & 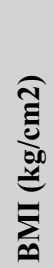 & $\frac{\underbrace{o}_{0}}{\frac{a}{\pi}}$ & 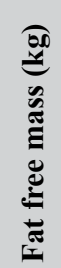 & 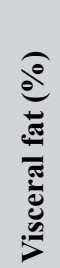 \\
\hline
\end{tabular}




\begin{tabular}{|c|c|c|c|c|c|c|c|}
\hline 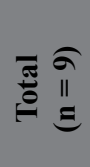 & $\begin{array}{l}\hat{i} \\
+ \\
a \\
\vec{i}\end{array}$ & $\begin{array}{l}\stackrel{+}{N} \\
\text { I } \\
\text { I }\end{array}$ & 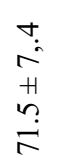 & $\begin{array}{l}0 \\
\dot{r} \\
+ \\
\vec{r} \\
\ddot{v}\end{array}$ & 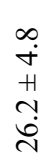 & 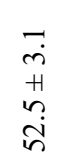 & 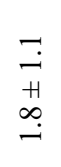 \\
\hline 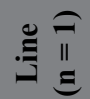 & $\stackrel{\infty}{\sim}$ & $\stackrel{\infty}{\infty}$ & $\begin{array}{l}+ \\
\dot{0}\end{array}$ & $\stackrel{\circ}{\vec{\lambda}}$ & $\ddot{n}$ & $\stackrel{n}{n}$ & $\stackrel{\circ}{-}$ \\
\hline 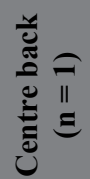 & 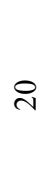 & $\begin{array}{l}0 \\
\ddot{1} \\
-1\end{array}$ & $\stackrel{n}{6}$ & $\widehat{\mathrm{N}}$ & $\vec{i}$ & $\stackrel{n}{\infty}$ & $\stackrel{0}{-}$ \\
\hline 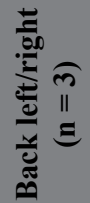 & $\begin{array}{l}\vec{H} \\
\ddot{H} \\
\text { ì }\end{array}$ & $\begin{array}{l}3 \\
\text { H } \\
\text { i } \\
\text { I }\end{array}$ & $\begin{array}{l}a \\
a \\
+ \\
a \\
\infty \\
0\end{array}$ & $\begin{array}{l}\hat{a} \\
+1 \\
\infty \\
\dot{\vec{N}}\end{array}$ & $\begin{array}{l}\forall \\
\dot{v} \\
+ \\
\ddot{v}\end{array}$ & 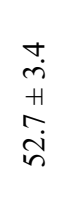 & $\begin{array}{l}0 \\
0 \\
H \\
? \\
\dddot{\eta}\end{array}$ \\
\hline 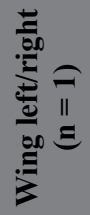 & $\tilde{\imath}$ & $\stackrel{\infty}{\infty}$ & $\vec{\infty}$ & $\underset{\sim}{\stackrel{\sim}{\sim}}$ & ñ & $\stackrel{N}{\stackrel{N}{n}}$ & $\stackrel{\circ}{+}$ \\
\hline 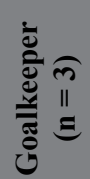 & $\begin{array}{l}0 \\
\dot{+} \\
+1 \\
0 \\
\dot{i}\end{array}$ & $\begin{array}{l}m \\
\infty \\
H \\
+ \\
\pm \\
I\end{array}$ & $\begin{array}{l}0 \\
+ \\
H \\
\dot{H} \\
\ddot{r}\end{array}$ & $\begin{array}{l}0 \\
\dot{i} \\
+ \\
\dot{a} \\
\dot{+}\end{array}$ & $\begin{array}{l}n \\
\text { ñ } \\
n \\
\stackrel{2}{2}\end{array}$ & $\begin{array}{l}\stackrel{a}{r} \\
+ \\
\ddot{n} \\
\ddot{n}\end{array}$ & $\begin{array}{l}\vec{H} \\
\dot{H} \\
\dot{N}\end{array}$ \\
\hline$\frac{\frac{0}{2}}{\frac{\pi}{\pi}}$ & 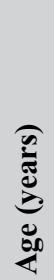 & 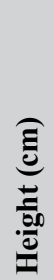 & 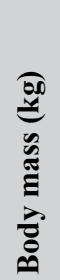 & 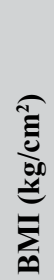 & 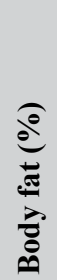 & 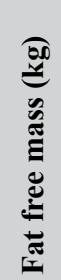 & 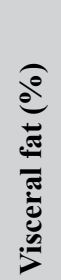 \\
\hline
\end{tabular}




\section{Energy and Macronutrient Intakes}

\section{Recommended Energy and Macronutrient Intakes}

For handball players, there are no specific recommendations for energy and macronutrient intake available from the literature. However, we calculated the average RDEIs for training days, match days and days off from the individual FFM of each male player. These amounted to: $4054 \pm 248 \mathrm{kcal} ; 4587 \pm 289 \mathrm{kcal} ; 3413 \pm 193 \mathrm{kcal}$ for training days, match days and days off, respectively. These calculated RDEIs showed significant differences between the days $(\mathrm{F}=1703,75 ; \mathrm{p}<0,025)$.

For the female handball players included in this study, the RDEI for training days was $3173 \pm 176 \mathrm{kcal}$ and for days off $2646 \pm 108 \mathrm{kcal}$, respectively. For match days we calculated: $3602 \pm 218 \mathrm{kcal}$. The calculated RDEIs showed significant differences between training days, match days and days off $(\mathrm{F}=539,97 ; \mathrm{p}<0,025)$.

In general, the recommendations for nutrient intake are not specifically listed for various sports activities, and, with the exception of specific micronutrients, do not mention any specific distinctions between the genders (Burke, Hawley, Wong, \& Jeukendrup, 2011; Campbell et al., 2007; Rodriquez et al., 2009; Thomas et al., 2016). Thus, the nutritional recommendations for handball stated here, are presumed to be in a similar range as the recommendations that are mentioned for similar team sports activities like football, basketball, volleyball, and others. The fat intake is recommended to amount to $20-35 \%$ of the daily energy intake (American Dietetic Association et al., 2009; Rodriquez et al., 2009). For carbohydrates, it is recommended to consume 6-10 g/kg BM/day (Burke et al., 2011; American Dietetic Association et al., 2009; Rodriquez et al., 2009), while for proteins 1.4-1.6 g/kg BM/day (Campbell et al., 2007).

\section{Energy and Macronutrient Intakes in Male Handball Players}

Figure 1 shows the average energy and macronutrient intakes for the participating male handball players on the training day, match day and day off, respectively. Fat intake is expressed in percentage of the individual daily energy intake, while the carbohydrates and protein intakes are expressed in gram per kilogram of body mass.

Figure 1A shows the actual recorded and the recommend energy intakes for three days. From the food diaries in this study, it was shown that on average (white bars of Figure 1A), the male handball players had the highest energy intake on a match day (3290 kcal), a somewhat lower on training day $(2871 \mathrm{kcal})$ and the least on a day off (2557 kcal). Repeated ANOVA measures on these actual recorded energy intakes, did not find significant differences between the three days for the included male handball players $(\mathrm{F}=2.44, \mathrm{p}=0.118)$.

However, the theoretical RDEIs show statistical differences between the three days of the training cycle, as explained in section Recommended Energy and Macronutrient 
Kaja TERAŽ, Cécil J. W. MEULENBERG: NUTRITIONAL INTAKE OF SLOVENIAN SEMI-PROFESSIONAL HANDBALL PLAYERS, 129-147

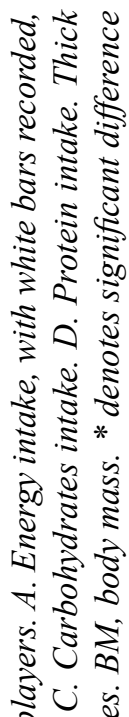

$\ddot{2} \dot{0} \dot{2}$

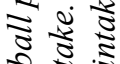

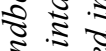

¿

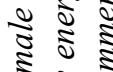

궁

ป

$\frac{\pi}{6}$

$\therefore$ os on

$\approx \underset{2}{\approx}$

ป

इ 20

용

용

ป

施

के ए

हैं ई

ป ปे

간 $\frac{2}{2}$

2 0 -

o.

곡ำ

o

$\pm \cong$

$\therefore \approx 0$

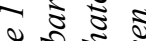

$\div 3$

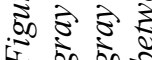
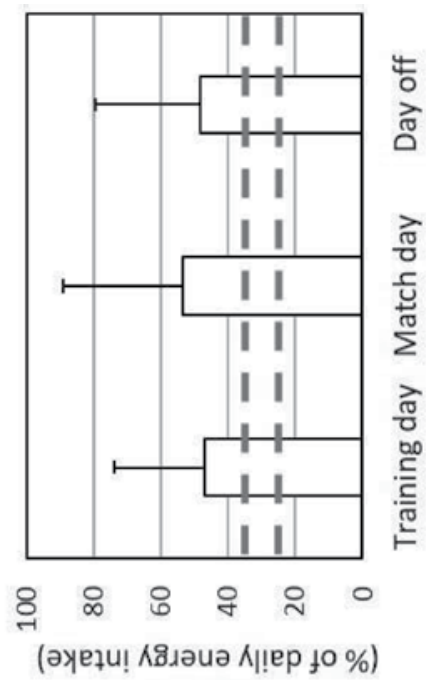
әүети! 孔е

$\infty$

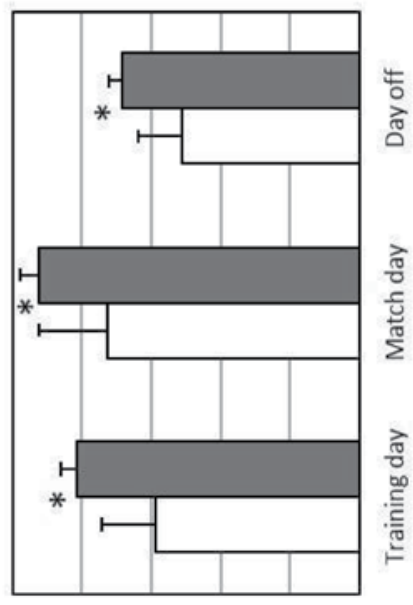

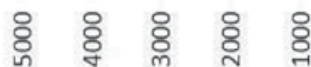
$\lessdot$

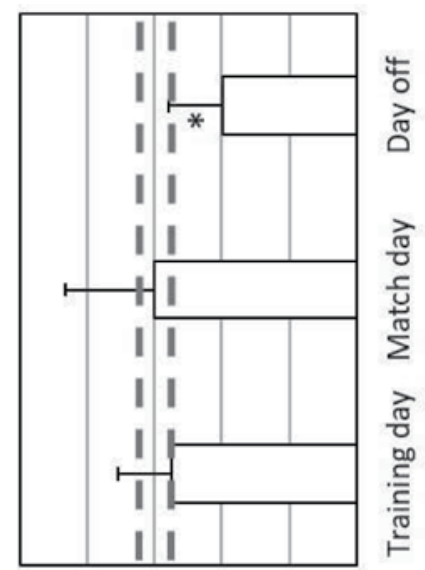

ก $\sim$ ก

(Кep/wg 8y/8)

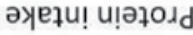

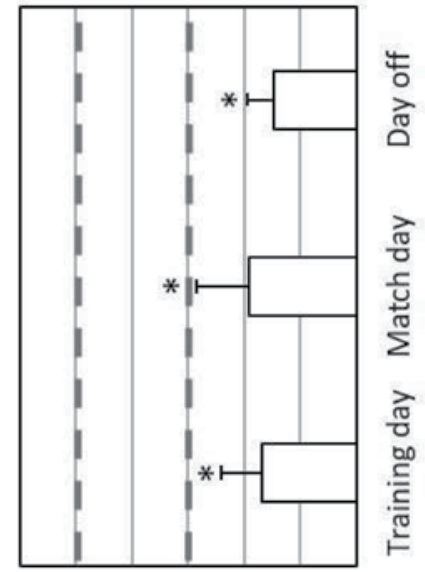

$\stackrel{-}{\sim} \infty \omega \forall \sim 0$

(Кep/wg 8y/8)

әуеұи! әтелрКчоqлеЈ 
Kaja TERAŽ, Cécil J. W. MEULENBERG: NUTRITIONAL INTAKE OF SLOVENIAN SEMI-PROFESSIONAL HANDBALL PLAYERS, 129-147

Intakes. Consequently, the actual energy intake (from the food diary) met the theoretical energy recommendation by $72.4 \%, 78.7 \%$ and $74.7 \%$, respectively on a training day, a match day and a day off. For each of the three days separately, the recorded average daily energy intake differed statistically from the RDEI (denoted by the * in Figure 1A).

While the recommendations for the intake of fat were generally fulfilled (Figure 1B), the carbohydrate intake was generally lower than the recommended range (Figure 1C), and the recorded protein intake for male players on the training and match days were within the recommended range, while it was out of the recommended range on a day off (Figure 1D).

For the male handball players, we calculated more in detail the percentage of players that reached the minimal recommendations of energy and macronutrient intakes on the specific days. This is illustrated in Figure 2. Only 38.3\% fulfilled the theoretical RDEI on a match day, $18.8 \%$ for the training day, and only $28,6 \%$ of the male players obtained enough energy during the day off. In general, carbohydrates and proteins

Figure 2: Percentage of male players reaching the recommended energy and macronutrient levels. White bars: energy, calculated from RDEI as in section 4.2.1; Gray bars: carbohydrates, calculated from lower recommended limit; Hatched bars: protein, calculated from lower recommended limit; Black bars: fat, calculated from upper recommended limit.

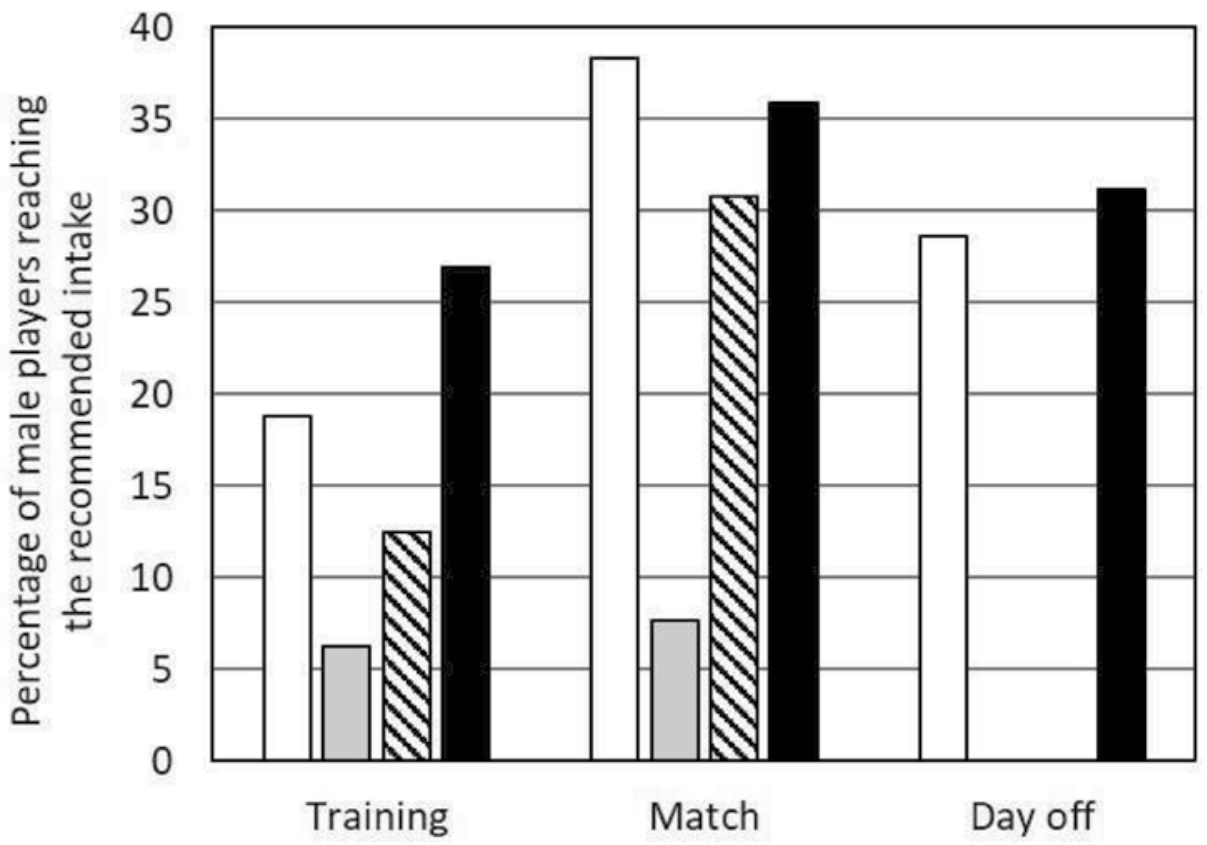


Kaja TERAŽ, Cécil J. W. MEULENBERG: NUTRITIONAL INTAKE OF SLOVENIAN SEMI-PROFESSIONAL HANDBALL PLAYERS, 129-147

recommendations were met poorly for a training day $(6.3 \% ; 12.5 \%$, respectively). For days off none of the players fulfilled the recommendations for both carbohydrates and proteins. While on a match day, only $31 \%$ of the male players reached the recommended amount of proteins. The percentage of players reaching the minimal recommendation for fat intake was more than 25\% during all three days (about $50 \%$ was within the recommended range for all days). Moreover, in fact, it was observed that the percentage of players overconsuming fat was more than $38 \%$ (based on the upper recommendation limit).

\section{Energy and Macronutrient Intakes in Female Handball Players}

During the observational week of this study, the recorded daily energy intakes for the 9 female players on average were $1690 \pm 750 \mathrm{kcal}$ for a training day, and $1284 \pm 500$ for a day off (Figure 3A). As already mentioned in section 4.2.1, the calculated RDEIs showed significant differences between a training day, and a day off ( $\mathrm{F}=539.97$; $\mathrm{p}$ $<0.025$ ), which can also be observed in Figure 3A (gray bars). Consequently, on a training day, $52.3 \%$ of the energy recommendation was met, while on a day off it reached only $47.7 \%$. To find out whether the differences in the RDEIs and the actual recorded food intake for the female participants were present, a repeated measures analysis was conducted. No significant difference in energy intake between the different days was found $(\mathrm{F}=1.78, \mathrm{p}=0.224)$. However, for each day separately a statistically significant difference between RDEI and actual recorded energy intake was established (denoted by the asterisks in figure $3 \mathrm{~A}$ ).

In general, the recommended fat intake for both days was reached (Figure 3B). While the actual intakes of both carbohydrates and protein were below the recommendations (Figures 3C and D).

Figure 4 shows the fulfillment of energy and macronutrient recommendations in more detail. The percentage of players that reached the daily energy intake was low ( $14.3 \%$ for both days), while none reached the carbohydrate recommendations, and only $11.1 \%$ and $14.3 \%$ of the players fulfilled the protein intake on training and resting days respectively. Strikingly, the consumption of fat was high, and reached the upper limit of recommendation among more than $55 \%$ of female players $(77.8 \%$ consume an adequate amount of fat on the training day and $57.1 \%$ on the day off). 
Kaja TERAŽ, Cécil J. W. MEULENBERG: NUTRITIONAL INTAKE OF SLOVENIAN SEMI-PROFESSIONAL HANDBALL PLAYERS, 129-147
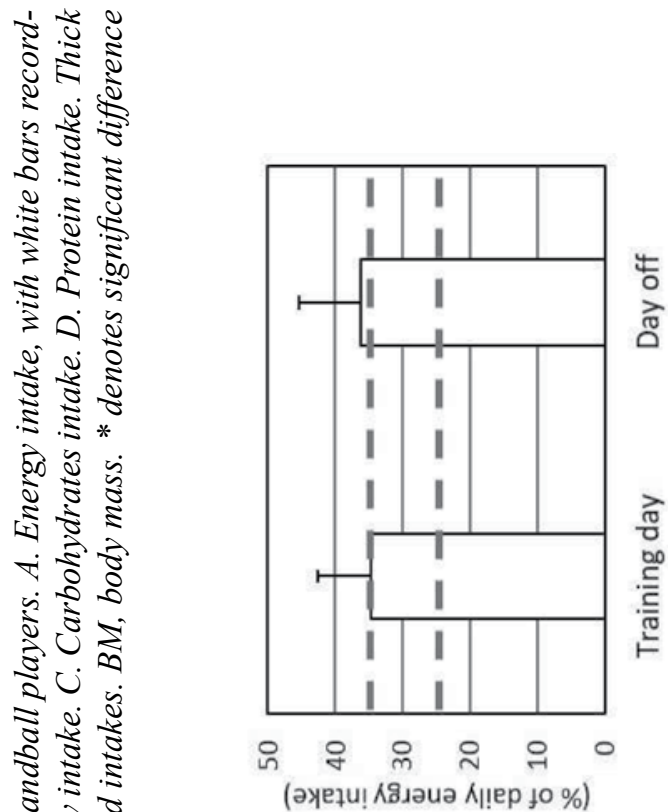

$\underset{2}{2}$ के

¿

$\sqrt{3}, \frac{9}{2}$

ì $\frac{0}{0}$

ปे

$\approx 0$

:

$\approx$ ป

$2 \frac{2}{2} \frac{2}{2}$

站 20

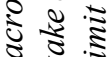

ミ.

ป

○近

के वं ح

ป จ

ป

궁

ช

2

20 \&

के

\.

$\therefore=0$

ช

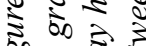

के

$$
\text { әуетu! zеঊ }
$$

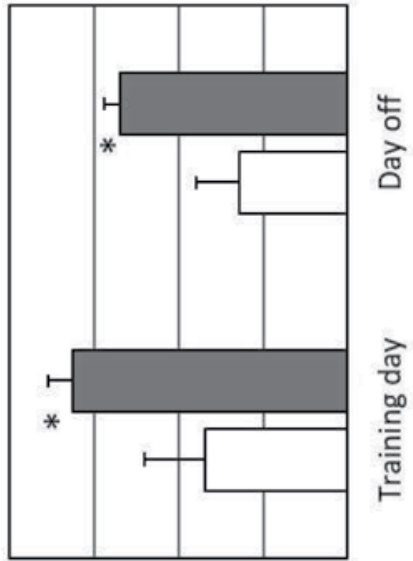

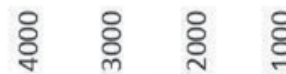

$\varangle$

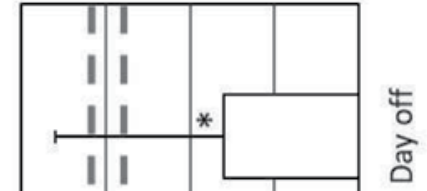

әуети! uाวาодd

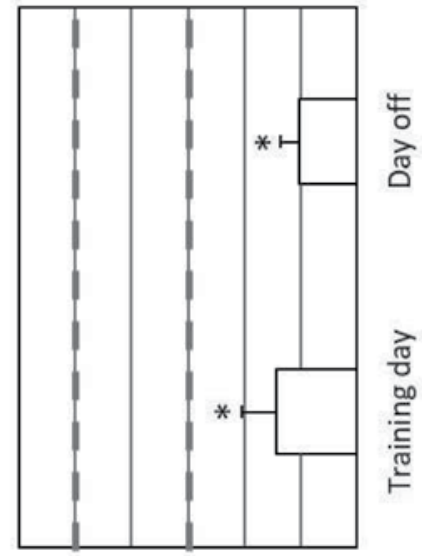

유 $\infty \omega \forall \sim 0$

(Кep/Wg 8y/8)

әуети! sәzедркцоqлез 
Kaja TERAŽ, Cécil J. W. MEULENBERG: NUTRITIONAL INTAKE OF SLOVENIAN SEMI-PROFESSIONAL HANDBALL PLAYERS, 129-147

Figure 4: Percentage of female players reaching the recommended energy and macronutrient levels. White bars: energy, calculated from RDEI as in section 4.2.1; Gray bars: carbohydrates, calculated from lower recommended limit; Hatched bars: protein, calculated from lower recommended limit; Black bars: fat, calculated from upper recommended limit.

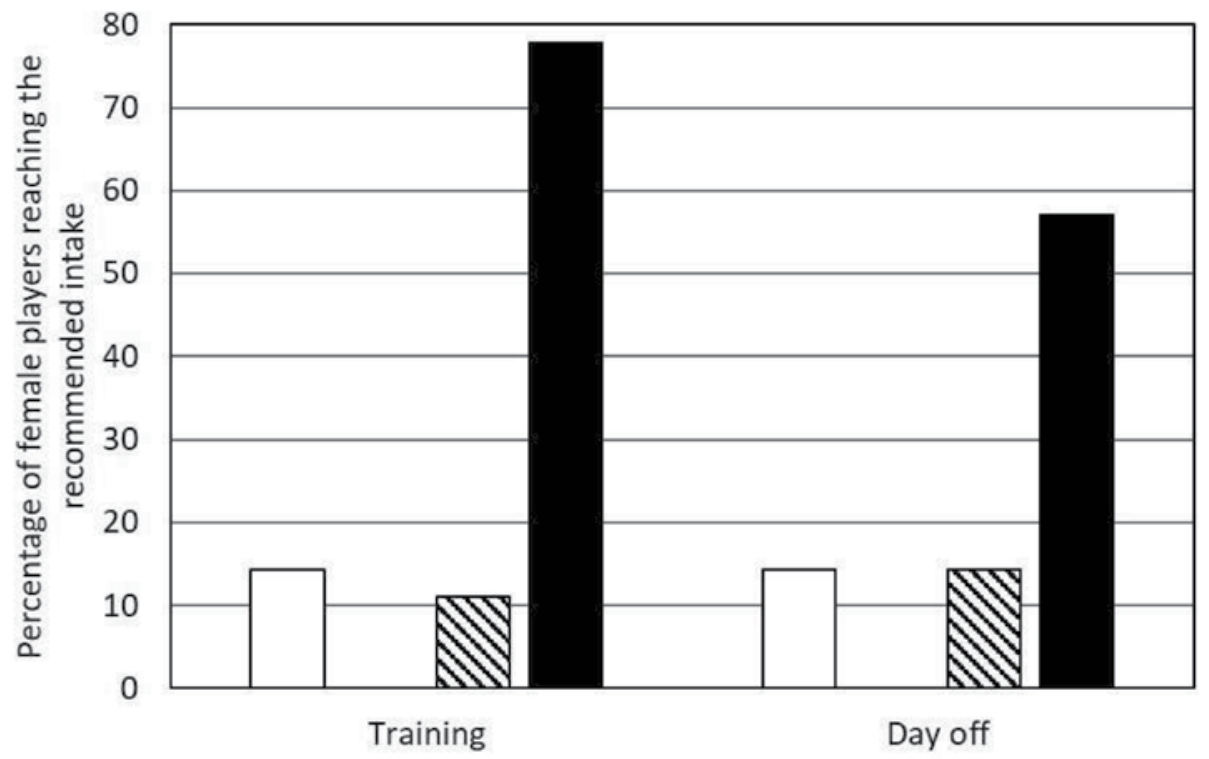

\section{DISCUSSION}

The aim of the study was to assess the anthropometric and body composition data in the players of two semi-professional handball teams from the Slovenian national league and to evaluate whether they meet the recommended nutritional intakes of energy and macronutrients. Therefore, players were asked to record, in a detailed way, their daily food intake for the 7 days of a training microcycle.

The heights of the male players, shown in Table 1, are comparable to the heights as previously reported (Chaouachi et al., 2009; Ghobadi, Rajabi, Farzad, Bayati, \& Jeffreys, 2013; Molina-López et al., 2013; Massuca, Branco, Miarka, \& Fragoso, 2015; Šibila \& Pori, 2009; Sporiš, Vuleta, Vuleta, \& Milovanović, 2010). In relation to the field position, the current players' heights follow the recent reports from large sets of professional players $(n=406$, Ghobadi et al., 2013; $n=161$, Massuca et al., 2015). Furthermore, the average of $90.4 \mathrm{~kg}$ of body mass falls within the range of 82.2 to 96 $\mathrm{kg}$ as reported by previous studies in male handball players (Chaouachi et al., 2009; Ghobadi et al., 2013; Massuca et al., 2015; Molina-López et al., 2013; Šibila \& Pori, 2009; Sporiš et al., 2010). 
Several studies reported body fat, but only a few specifically related to the field position for male handball players, not differentiating between left, right or centrebacks ( $\mathrm{n}=21$, Chaouachi et al., 2009; $\mathrm{n}=78$, Šibila \& Pori, 2009; $\mathrm{n}=92$, Sporiš et al., 2010). The averaged percentages of body fat ranged from 11.2 to $15.4 \%$ (Chaouachi et al., 2009; Molina-López et al., 2013; Šibila \& Pori, 2009; Sporiš et al., 2010), while the male players from the present study have a slightly higher averaged percentage of body fat, amounting to $16.2 \%$. In addition, the average level of visceral fat for the male handball players in the present study was of level 3.1. Unfortunately, other studies do not report the measurement of visceral fat, though up to 12 is considered to be in a healthy physiological range (Tanita Corporation of America Inc., 2013), with athletes most likely falling into the lower levels.

Concerning muscle mass, most studies report a detailed recording of muscle mass from body weight measurements (Chaouachi et al., 2009; Ghobadi et al., 2013; Massuca et al., 2015; Šibila \& Pori, 2009; Sporiš et al., 2010). The muscle mass in the present study is obtained as the percentage of fat-free mass (FFM), that includes bone mass. Hence, a detailed comparison is not possible. On the other hand, the averaged body mass index for the current sample of players amounts to $25.9 \pm 2.3 \mathrm{~kg} / \mathrm{m} 2$, that is identical to the large set reported by Ghobadi and co-workers $(25.5 \pm 2.1 \mathrm{~kg} / \mathrm{m} 2)$, as well as to a small sample of 14 Spanish professional male handball players $(24.7 \pm 1.1$ $\mathrm{kg} / \mathrm{m} 2$, (Molina-López et al., 2013).

Only a few studies report anthropometric data for female handball players $(\mathrm{n}=24$, Michalsik, Madsen, \& Aagaard, 2013; $\mathrm{n}=16$, Weber, Kehl, \& Fonseca Moreira, 2012). The presently reported average values for height and weight (Table 2, $174.1 \pm 7.2 \mathrm{~cm}$; $71.5 \pm 7.4 \mathrm{~kg}$ ) are comparable with the Danish data $(174.2 \mathrm{~cm}$ and $70.3 \mathrm{~kg}$, (Michalsik et al., 2013). While for Brazilian players both height and weight are smaller $(164.2 \mathrm{~cm}$ and $56.8 \mathrm{~kg}$ ) with a percentage of body fat of $23.2 \%$ (Weber et al., 2012). In contrast, the present sample of female players displayed $26.2 \%$ of body fat. In addition, the Brazilian FFM was lower and amounted to $47.9 \mathrm{~kg}$, as compared to $52.5 \mathrm{~kg}$ in our study. Thus, overall, the Brazilian female handball players seem to be somewhat smaller and leaner. Additionally, we report average visceral fat amounting to level 1.8 that is within the normal physiological range (Tanita Corporation of America Inc., 2013).

Although the literature is limited in providing the anthropometric and body composition data for professional male and female handball players, we can assume that the data presented in Tables 1 and 2 are representative of semi-professional Slovenian National League handball players, and besides are within the normal range for handball players in general.

The daily energy intake for team sports athletes has recently been found structurally too low (Jenner et al., 2019). In the present study, an energy deficient of about 800 to $1100 \mathrm{kcal}$ per day in males, and even $1500 \mathrm{kcal}$ in females, has been found during the current microcycle. However, the studies specifically focused on the nutritional intake of handball players are limited. Among 6 Portuguese professionals, an average energy intake of $4652 \mathrm{kcal}$ was found (Silva et al., 2017), which is fairly high, but seems to be adequate. On the other hand, a study among 14 professional Spanish male handball 
Kaja TERAŽ, Cécil J. W. MEULENBERG: NUTRITIONAL INTAKE OF SLOVENIAN SEMI-PROFESSIONAL HANDBALL PLAYERS, 129-147

players measured $2975 \mathrm{kcal}$ per day (Molina-López et al., 2013), which is comparable to our training day data $(2871 \mathrm{kcal} /$ day $) .16$ Brazilian female players had an energy intake of 1883 per day (comparable with the $1690 \mathrm{kcal}$ per day found here), which was mentioned to be at least 220-440 kcal less than the recommended range (Weber et al., 2012). Interestingly, when the Spanish study introduced a nutritional education programme, after 8 weeks the intake increased with an additional $380 \mathrm{kcal}$ per day (Molina-López et al., 2013). After finishing the education, a new assessment after 8 weeks showed that the intake remained at $3329 \mathrm{kcal}$ per day. While these studies do not mention the amount of players that meet the recommendations, it seems plausible that specific nutritional training and education, especially with the involvement of an expert sports dietitian, would yield higher percentages of players fulfilling the recommendations. Just like the recent systematic literature review by Jenner et al., (2019), we emphasize the need to prepare and include, sport-specific and player-position nutritional recommendations/education, to enhance performance.

Next to these generally low energy intakes, it became increasingly important to known whether our participants reached the recommended levels of macronutrients. As we suspected, the intake of macronutrients was not adequately assorted. The actual intake of carbohydrates was statistically different from the recommendations on all days, both for males and females. Such a poor carbohydrates intake for team sport athletes has been reported before (Holway \& Spriet, 2011), while on the other hand, sufficient carbohydrate intake in male soccer teams is reported in predominantly older literature (Hickson, Johnson, Schrader, \& Stockton, 1987; Jacobs, Westlin, Karlaaon, Rasmusson, \& Houghton, 1982; Rico-Sanz, 1998). For women, the highest recorded carbohydrates intake was $5.2 \mathrm{~g} / \mathrm{kg} \mathrm{BM}$ /day (Clark, Reed, Crouse, \& Armstrong, 2003). This does not reach the most recent minimal recommendation level of $6 \mathrm{~g} / \mathrm{kg} \mathrm{BM} /$ day that is based on soccer players (Burke et al., 2011; American Dietetic Association et al., 2009; Rodriquez et al., 2009). Despite that metabolic demands between football and handball might differ, it is also suggested that recommendations for the intake of carbohydrates in team sports are set too high. Based on football, recommendations have been issued ranging from 5-7 g/kg BM/day (Consensus Statement, 2006; Holway \& Spriet, 2011).

The protein intake of the male players was insufficient only on the day off $(1,0 \pm 0,4$ $\mathrm{g} / \mathrm{kg} \mathrm{BM} /$ day), while for female athletes, protein intake was insufficient on training days and days off. It is important to notice that the official recommendations issued by the establish sports institutes (International Society of Sports Nutrition - ISSN; American Academy of Sports Medicine - ACSM; and Medical Commission of the International Olympic Committee - IOC), are of a very general character. Usually recommending a range in the high amounts, facilitating for each individual (handball) player to adjust the intake, according to their personal wishes.

Regarding the fat intake, for all players, both males and females, no statistical significant differences with the literature recommendations were observed. However, while for females the fat intake was within the recommended range, for males an excessive intake was noticed for all days. 
High fat intake and inadequate carbohydrate intake (and on certain days, inadequate protein intake), can be linked to the anthropometric characteristics of handball players. A relatively high percentage of body fat may be due to the excess of fat intake. Inadequate macronutrient ratios in combination with low energy intake, can also be interpreted as an excess of body fat, and consequently, a lower percentage of muscle mass. Appropriate food choices, especially less fatty foods or foods rich in monounsaturated and polyunsaturated fatty acids, improve the anthropometric values of both males and females, optimizing their physical performance (Burke \& Cox, 2010; Fink \& Mikesky, 2015). For both the male and female athletes of this study, the proportion of macronutrients (carbohydrates, proteins and fats) is not in line with the recommendations of global sports institutions (Burke et al., 2011; Campbell et al., 2007; American Dietetic Association et al., 2009; Rodriquez et al., 2009; Thomas et al., 2016). The present study shows that the participating handball players, of both genders, adhere to a high fat intake, and, above all, low carbohydrates and protein intakes.

The present study comes with several limitations. Food diaries do not always reflect the actual food intake, as self-report is subject to recall errors and reporting bias, both general limitations of this method. Some individuals have reported very low energy intake in relation to their actual body composition. Knowing that a high percentage of body fat is due to inadequate nutrition, we assume that their reporting was not reliable. Here we see an opportunity to further explore and verify the reporting of data in athletes who have weight problems. The reporting was only performed during one week. For a more accurate information and a reliable account of the nutritional status of handball players on match days, their nutrition should be recorded preferably over a whole season, especially during multiple matches. Despite the fact that this study reports on a limited number ( 9 females and 17 males), it adds to previous energy intake studies. The anthropometric data of our study were in fact comparable with those from previous studies. Thus, despite the limitations within the current study, the results bring a relevant addition to the published literature on hand ball players' nutritional intake.

\section{CONCLUSION}

In conclusion, the Slovenian male and female handball players evaluated in the current study are not adequately nourished considering the current nutritional recommendations. They do not have optimally distributed macronutrient intake during their whole-day energy intake, and these inadequate macronutrient values could affect their energy metabolism and performance. Both male and female athletes consume especially too little carbohydrates and too much fat. Although the intake of protein for male players is within the recommended limits, the macronutrients introduced are not in the optimal ratio.

Handball, and other team sports, demand different exposure to the efforts in terms of playing positions, and thus, individual consultations. However, the number of scientific studies regarding nutrition and team sports are limited, and often include only a small 
Kaja TERAŽ, Cécil J. W. MEULENBERG: NUTRITIONAL INTAKE OF SLOVENIAN SEMI-PROFESSIONAL HANDBALL PLAYERS, 129-147

number of players. Thus, little comparable research is available. It is for these reasons that it is difficult to formulate recommendations that would suit all players and thus optimize their performance. Nevertheless, introducing nutritional instructions and interventions could improve the players' eating habits and thus their psychophysical fitness.

\section{Conflicts of Interest}

The authors declare that no conflicts of interest exist.

\section{Funding}

This manuscript was prepared as part of the research programme Kinesiology for Quality of Life (P5-0381) funded by the Slovenian Research Agency.

\section{Ethical Aproval}

The approval for this study by the Ethics Committee of the Republic of Slovenia is located under 0120-132 / 2016 KME 55/03/16.

\section{REFERENCES}

Ainsworth, B. E., Haskell, W. L., Herrmann, S. D., Meckes, N., Bassett, D. R., TudorLocke, C., ... Leon, A. S. (2011). Compendium of physical activities: A second update of codes and MET values. Medicine \& Science in Sports \& Exercise, 42(2), 1575-1581. https://doi.org/10.1249/MSS.0b013e31821ece12.

American Dietetic Association, Dietitians of Canada, American College of Sports Medicine, Rodriquez, N. R., DiMarco, N. M., \& Langley, S. (2009). American College of Sports Medicine position stand. Nutrition and Athletic Performance. Medicine \& Science in Sports \& Exercise, 41(3), 709-731. https://doi.org/10.1249/MSS.0b013e31890eb86.

Burke, L. M., \& Cox, G. (2010). The complete guide to food for sports performance: A guide to peak nutrition for your sport (3rd ed.). Crows Nest: Allen and Unwin.

Burke, L. M., Hawley, J. A., Wong, S. H. S., \& Jeukendrup, A. E. (2011). Carbohydrates for training and competition. Journal of Sports Sciences, 29(1), 17-29. https://doi.org/1 0.1080/02640414.2011.585473.

Campbell, B., Kreider, R. B., Ziegenfuss, T., La Bounty, P., Roberts, M., Burke, D., ... Antonio, J. (2007). International Society of Sports Nutrition position stand: Protein and exercise. Journal of the International Society of Sports Nutrition, 4(1), 8. https://doi. org/10.1186/1550-2783-4-8.

Chaouachi, A., Brughelli, M., Levin, G., Boudhina, N. B. B., Cronin, J., \& Chamari, K. (2009). Anthropometric, physiological and performance characteristics of elite 
team-handball players. Journal of Sports Sciences, 27(2), 151-157. https://doi. org/10.1080/02640410802448731.

Clark, M., Reed, D. B., Crouse, S. F., \& Armstrong, R. B. (2003). Pre- and post-season dietary intake, body composition, and performance indices of NCAA division I female soccer players. International Journal of Sport Nutrition and Exercise Metabolism, 13(3), 303-319. https://doi.org/10.1123/ijsnem.13.3.303.

Consensus Statement. (2006). Nutrition for football: The FIFA/F-MARC Consensus Conference. Journal of Sports Sciences, 24(7), 663-664. https://doi. org/10.1080/02640410500482461.

Cunningham, J. J. (1980). A reanalysis of the factors influencing basal metabolic rate in normal adults. The American Journal of Clinical Nutrition, 33(11), 2372-2374. https:// doi.org/10.1093/ajen/33.11.2372.

Debeljak, P., Debeljak, D., Hlastan-Ribič, C., Salobir, K., \& Pokorn, D. (2004). Referenčne vrednosti za vnos hranil [Reference values for nutrient intakes]. Ljubljana: Ministrstvo za zdravje.

Fink, H. H., \& Mikesky, A. E. (2015). Practical applications in sports nutrition. Jonas \& Bartlett Learning.

Ghobadi, H., Rajabi, H., Farzad, B., Bayati, M., \& Jeffreys, I. (2013). Anthropometry of World-Class elite handball players according to the playing position: reports from Men's Handball World Championship 2013. Journal of Human Kinetics, 39(1), 213220. https://doi.org/10.2478/hukin-2013-0084.

Hickson, J. F. Jr., Johnson, C. W., Schrader, J. W., \& Stockton, J. E. (1987). Promotion of athletes' nutritional intake by a university foodservice facility. Journal of the American Dietetic Association, 87, 926-927.

Holway, F. E., \& Spriet, L. L. (2011). Sport-specific nutrition: Practical strategies for team sports. Journal of Sports Sciences, 29(sup1), S115-S125. https://doi.org/10.1080/0264 0414.2011.605459.

International Olympic Committee. (2011). IOC consensus statement on sports nutrition 2010. Journal of Sports Sciences, 29(sup1), S3-S4. https://doi.org/10.1080/02640414. 2011.619349.

Jacobs, I., Westlin, N., Karlsson, J., Rasmusson, M., \& Houghton, B. (1982). Muscle glycogen and diet in elite soccer players. European Journal of Applied Physiology and Occupational Physiology, 48(3), 297-302. https://doi.org/10.1007/BF00430219.

Jenner, S. L., Buckley, G. L., Belski, R., Devlin, B. L., \& Forsyth, A. K. (2019). Dietary intakes of professional and semi-professional team sport athletes do not meet sport nutrition recommendations - a systematic literature review. Nutrients, 11(5), 1160. https:// doi.org/10.3390/nu11051160.

Kreider, R. B., Wilborn, C. D., Taylor, L., Campbell, B., Almada, A. L., Collins, R., ... Antonio, J. (2010). ISSN exercise \& sport nutrition review: Research \& recommendations. Journal of the International Society of Sports Nutrition, 7(1), 7. https://doi. org/10.1186/1550-2783-7-7.

Massuca, L., Branco, B., Miarka, B., \& Fragoso, I. (2015). Physical fitness attributes of team-handball players are related to playing position and performance level. Asian Journal of Sports Medicine, 6(1), e24712. https://doi.org/10.5812/asjsm.24712.

Michalsik, L., Madsen, K., \& Aagaard, P. (2013). Match performance and physiological capacity of female elite team handball players. International Journal of Sports Medicine, 35(7), 595-607. https://doi.org/10.1055/s-0033-1358713. 
Kaja TERAŽ, Cécil J. W. MEULENBERG: NUTRITIONAL INTAKE OF SLOVENIAN SEMI-PROFESSIONAL HANDBALL PLAYERS, 129-147

Molina-López, J. M., Molina J. M., Chirosa, L. J., Florea, D., Sáez, L., Jiménez, J., ... Planells, E. (2013). Implementation of a nutrition education program in a handball team; consequences on nutritional status. Nutricion Hospitalaria, 28(4), 1065-1076. https://doi.org/10.3305/nh.2013.28.4.6600.

Rico-Sanz, J. (1998). Body composition and nutritional assessments in soccer. International Journal of Sport Nutrition, 8(2), 113-123. https://doi.org/10.1123/ijsn.8.2.113.

Rodriquez, N. R., DiMarco, N. M., Langley, S., American Dietetic association, Dietitians of Canada, \& American College of Sports Medicine. (2009). Position of the American Dietetic Association, Dietitians of Canada, and the American College of Sports Medicine: Nutrition and Athletic Performance. Journal of the American Dietetic Association, 109(3), 509-527. https://doi.org/10.1016/j.jada.2009.01.005.

Silva, A. M., Matias, C. N., Santos, D. A., Thomas, D., Bosy-Westphal, A., Müller, M. J., ... Sardinha, Lu. B. (2017). Compensatory changes in energy balance regulation over one athletic season. Medicine \& Science in Sports \& Exercise, 49(6), 1229-1235. https://doi.org/10.1249/MSS.0000000000001216.

Sporiš, G., Vuleta, D., Vuleta, D. Jr., \& Milovanović, D. (2010). Fitness profiling in handball: Physical and physiological characteristics of elite players. Collegium Antropologicum, 34(3), 1009-1014. Retrieved from https://hrcak.srce.hr/59364.

Spronk, I., Heaney, S. E., Prvan, T., \& O'Connor, H. T. (2015). Relationship between general nutrition knowledge and dietary quality in elite athletes. International Journal of Sport Nutrition and Exercise Metabolism, 25(3), 243-251. https://doi.org/10.1123/ ijsnem.2014-0034.

Šibila, M., \& Pori, P. (2009). Position-Related Differences in Selected Morphological Body Characteristics of Top-Level Handball Players. Collegium Antropologicum, 33(4), 1079-1086. Retrieved from https://hrcak.srce.hr/51458.

Tanita Corporation of America Inc. (2013). Tanita Technical Bulletin: Visceral Fat Measurement. Retrieved from https://www.tanita.com/data/File/AdditionalResearch/VisceralFatMeasurmentp1.pdf?rev=72DE.

Thomas, D., Erdman, K., \& Burke, L. M. (2016). American College of Sports Medicine Joint Position Statement. Nutrition and Athletic Performance. Medicine \& Science in Sports \& Exercise, 48(3), 543-568. https://doi.org/10.1249/MSS.0000000000000852.

Weber, M. H., Kehl, C., \& Fonseca Moreira, J. C. (2012). Comparison of the dietetic and anthropometric profile of handball athletes during a training period. Fiep Bulletin, 82, 209-212. 